\title{
Prevalence of biomicroscopic findings in the anterior segment and ocular adnexa among schoolchildren in Natal/Brazil
}

\author{
Prevalência dos achados biomicroscópicos do segmento anterior e anexos oculares em \\ escolares deNatal/Brasil
}

\author{
Carlos Alexandre de Amorim Garcia ${ }^{1}$ \\ Francisco Irochima Pinheiro \\ Daniel Alves Monteneg'ro ${ }^{3}$ \\ Alexandre Henrique Bezerra Gomes ${ }^{4}$ \\ Fernando Oréfice ${ }^{5}$
}

\footnotetext{
${ }^{1}$ Professor of Ophthalmology. Federal University of Rio Grande do Norte - UFRN. Natal (RN) - Brazil.

${ }^{2}$ Medical resident. Department of Ophthalmology, Onofre Lopes University Hospital - HUOL, Federal University of Rio Grande do Norte - UFRN. Natal (RN).

${ }^{3}$ Medical resident. Department of Ophthalmology, Onofre Lopes University Hospital - HUOL, Federal University of Rio Grande do Norte - UFRN. Natal (RN). ${ }^{4}$ Professor of Ophthalmology - UFRN. Natal (RN).

${ }^{5}$ Professor of Ophthalmology. Federal University of Minas Gerais - UFMG. Belo Horizonte (MG).

Address to correspondence: Carlos Alexandre de Amorim Garcia - Rua Ceará Mirim, 316 - Natal (RN) CEP 59020-240

E-mail: prontoc.de.olhos@ digi.com.br

Recebido para publicação em 28.08.2003

Versão revisada recebida em 08.10 .2004

Aprovação em 15.12.2004

Nota Editorial: Após concluída a análise do artigo sob sigilo editorial e com a anuência da Dra. Saly Bugman Moreira sobre a divulgação de seu nome como revisora dele, agradecemos sua participação nesse processo.
}

\begin{tabular}{l} 
ABSTRACT \\
\hline Objective: To determine the prevalence of ocular findings of the external \\
structures and anterior segment of the eye, detected by biomicroscopic \\
examination in schoolchildren in Natal (RN) - Brazil. Methods: After \\
previous random selection, 1,024 pupils from elementary and secondary \\
public and private schools in the city of Natal were evaluated from March \\
to June 2001. All were submitted to preestablished standard research \\
norms, consisting of identification, demographic information, ophthal- \\
mologic biomicroscopic examination, with slit lamp, performed by ophthal- \\
mologists from the "Onofre Lopes" University Hospital. Results: Altera- \\
tions of the conjunctival and palpebral conditions were the most prevalent \\
(10.4\% and 6.2\% respectively). Follicles (4.2\%) and papillae (3.0\%) were \\
the frequent conjunctival lesions, while blepharitis (3.5\%) and meibomitis \\
(1.1\%) were the most detected abnormalities in the eyelids. Upon examining \\
the cornea, iris, lens and anterior vitreous, the most encountered findings \\
were nubecula (0.5\%), papillary membrane reliquiae (0.5\%), posterior \\
capsula opacity (0.8\%) and hyaloid arteria reliquiae (2.0\%). Conclusion: \\
The most prevalent findings affecting the external structures of the eye \\
such as eyelids and conjunctiva, consisted of blepharitis followed by \\
follicular reaction of the conjunctiva. The most prevalent abnormalities \\
in the cornea, iris, lens and anterior vitreous were nubecula, papillary \\
membrane reliquiae, posterior capsular opacity and hyaloid arteria \\
reliquiae, in that order.
\end{tabular}

Keywords: Anterior eye segment/pathology; Eye diseases/epidemiology; School health; Vision tests; Diagnostic techniques,ophthalmological; Cross-sectional studies

\section{INTRODUCTION}

Around the world, epidemiological studies of ocular alterations have been undertaken more and more routinely, generating debate over their cost/benefit ratio ${ }^{(1-2)}$. However, in developing countries, such as Brazil, there continues a notable lack of data with respect to the prevalence of ocular findings in different age groups ${ }^{(3)}$.

Besides contributing to planning preventive strategies, these studies frequently represent a selection of the analyzed population, leading to the diagnosis of ocular diseases in individuals who, in their great majority, had never been previously examined by an ophthalmologist, thus reflecting the poor health conditions under which these persons live ${ }^{(4)}$. 
Due to their greater exposure, structures such as eyelids, adnexa, conjunctiva and anterior segment of the eye are more susceptible to damage from trauma, sun exposure, infectious diseases, etc. However, their integrity can also be altered by defects in their embryological development, thus characterizing congenital malformations $\mathrm{s}^{(4)}$.

It is known that any ocular finding that impedes adequate foveal stimulus at an early age will lead to deprivation amblyopia which, if left untreated, will cause irreversible low visual acuity. Another important fact is that some ocular diseases, such as cataracts and corneal opacities can be satisfactorily treated if diagnosed ${ }^{(2)}$.

Such acquired or congenital defects are revealed by a simple and low-cost examination. Early diagnosis and treatment can usually promote healing of existing lesions, allowing individuals who present potential social-economic burdens to become economically active citizens ${ }^{(4)}$.

This can be seen by the endeavors of "Aide et Action", a French non-governmental organization, which initiated a program aimed at schoolchildren in Mwanza, Tanzania in 1996. Besides epidemiological studies, "Aide et Action" improved health conditions among the schoolchildren ${ }^{(4)}$.

The objective of this study is to provide epidemiological data on biomicroscopic ocular findings in the anterior segment and external structures of the eye in schoolchildren of Natal/Brazil.

\section{METHODS}

This is a transversal study of a randomly selected sample which consisted of people between the ages of 5 and 46 years, enrolled in private or public elementary or secondary schools in Natal, Brazil, in 2001.

Four sample populations, corresponding to the four sanitation districts that divide the city of Natal (North, South, East and West), were considered for purposes of the methodological model.

The number of students enrolled in public and private schools was 119,116 , distributed over the four districts of the city. The size of the sample was calculated based on this population. The procedure for sample selection comprised two separate stages: determining the general sample size and the random selection of the schools and pupils.

The sample size was determined from parameters obtained by the simple random sampling method for proportion, with a $3 \%$ error, an expected prevalence of $50 \%$ (as there was no $a$ priori information about this, maximum variance was used), and confidence interval (CI) of $95 \%$.

The calculated sample size was 1,100 pupils, distributed proportionally throughout the 341 schools in all four districts, in such a way as to establish the number of pupils that should be examined in each of the districts. Subsequently, the number of schools to be selected from each district was determined. Of 341 schools, 79 were chosen by the proportional probability of size method (PPS), using Delphi language software, to make up the sample, according to the nature of the institution (public and private), its level (elementary and secondary), and the study period (morning, afternoon and evening). Once the school was selected and classes per study period randomly drawn, students were then drawn from the class attendance sheet, obeying the proportionality observed in the population, and sent to the Ophthalmology Department, "Onofre Lopes" University Hospital (HUOL), Federal University of "Rio Grande do Norte" (UFRN). The protocol of the study was submitted to and approved by the UFRN Ethics Commission, number 18/01. All pupils were examined after submission of a consent form signed by their parents or guardians.

The pupils answered a standard questionnaire, applied by medicine professors and residents in Ophthalmology at the UFRN, which included identification, social-economic level ranking as well as personal and familial past nosologic data.

The pupils underwent ophthalmological examination which included: visual acuity measurement, diagnostic tests for strabismus (Hirschberg, Krimsky and occlusion test), refraction (retinoscopy under cycloplegia), biomicroscopy, tonometry and funduscopy.

For statistical analysis purposes, relative and punctual frequency of the study variables were determined and the data processed by SPSS computer program (Statistical Package for Social Science) Data Editor 10.0.

\section{RESULTS}

Of the 1,100 pupils in the sample, 1,024 appeared for the study. Of these, $415(40.5 \%)$ were males and $609(59.5 \%)$ females. Age varied from 5 to 46 years, the average being 13.99 years, the median 14 years and the mode 16 years.

Data analysis showed that external structures of the eye such as eyelids and conjunctiva represented the areas most affected by abnormalities. The percentage of patients with abnormal ocular findings in the conjunctiva was $10.4 \%$ of the sample. Of these, $4.2 \%$ were conjunctival follicles, $3.0 \%$ papillae, $1.8 \%$ nevus, $0.7 \%$ pterygium and $0.7 \%$ pinguecula (Table 1 ).

The percentage of ocular findings observed on eyelids and adnexa totaled $6.2 \%$, of which $3.5 \%$ consisted of blepharitis, $1.1 \%$ meibomitis, $0.8 \%$ epicanthus, $0.3 \%$ chalazion, $0.3 \%$ ptosis and $0.2 \%$ external hordeolum (Table 2 ).

The presence of nubecula accounted for $0.5 \%$ of the corneal findings whereas superior pannus was encountered in $0.4 \%$ of the sample. Leukoma was observed in three individuals $(0.3 \%)$ and foreign body in one $(0.1 \%)$, making up a total of 13 individuals with corneal alterations (Table 3 ).

Similarly to the low frequency of corneal abnormalities, biomicroscopic examination of the iris, lens and anterior vitreous revealed a small percentage of individuals with some finding. Of 1,024 students (100\%), only $1.1 \%$ presented iris changes, among which pupillary membrane reliquiae accoun- 
ted for $0.5 \%$, heterochromia $0.2 \%$, nevus $0.2 \%$, uveal ectropion and corectopia, $0.1 \%$ each (Table 4 ).

Among the lens findings, posterior capsular opacity was the most frequent, present in $0.8 \%$ of the pupils. Iris pigmention the anterior capsula was observed in $0.6 \%$ of the individuals, Mittendorf point in $0.5 \%$, posterior cortical opacity in $0.3 \%$, anterior cortical opacity in $0.1 \%$ and posterior subcapsular cataract in $0.1 \%$ (Table 5).

Anterior vitreous was the structure with the least diversity of findings, hyaloid arteria reliquiae being the only alteration reported in $2 \%$ of the pupils.

\section{DISCUSSION}

In general, the pattern of ocular diseases is constant. There are however inherent particularities to each study population ${ }^{(5)}$.

As shown in some prevalence studies, conditions which affect external structures, such as eyelids and conjunctiva, were the most frequently encountered due to their greater relation to the external environment ${ }^{(5)}$.

\begin{tabular}{|lcc|}
\hline \multicolumn{2}{|c|}{ Table 1. Biomicroscopic findings in the conjunctiva } \\
Findings & Number of persons & Percentage (\%) \\
Papillae & 31 & 3.0 \\
Pterygium & 7 & 0.7 \\
Pinguecula & 7 & 0.7 \\
Follicles & 43 & 4.2 \\
Nevus & 18 & 1.8 \\
Normal & 913 & 89.6 \\
Total & 1019 & 100.0 \\
\hline
\end{tabular}

Table 2. Biomicroscopic findings in the eyelids and adnexa

\begin{tabular}{lrc} 
Findings & Number of persons & Percentage (\%) \\
Blepharitis & 36 & 3.5 \\
Chalazion & 3 & 0.3 \\
External hordeolum & 2 & 0.2 \\
Epicanthus & 8 & 0.8 \\
Meibomitis & 11 & 1.1 \\
Ptosis & 3 & 0.3 \\
Normal & 957 & 93.8 \\
Total & 1020 & 100.0 \\
\hline
\end{tabular}

\begin{tabular}{|lcc|}
\hline \multicolumn{3}{|c|}{ Table 3. Biomicroscopic findings in the cornea } \\
Findings & Number of persons & Percentage (\%) \\
Leukoma & 3 & 0.3 \\
Foreign body & 1 & 0.1 \\
Superior pannus & 4 & 0.4 \\
Nubecula & 5 & 0.5 \\
Normal & 1006 & 98.7 \\
Total & 1019 & 100.0 \\
\hline
\end{tabular}

\begin{tabular}{|lcc|}
\hline \multicolumn{3}{|c|}{ Table 4. Biomicroscopic findings in the iris } \\
Findings & Number of persons & Percentage (\%) \\
Nevus & 2 & 0.2 \\
Uveal ectropion & 1 & 0.1 \\
Heterochromia & 2 & 0.2 \\
Pupillary membrane reliquiae & 5 & 0.5 \\
Corectopia & 1 & 0.1 \\
Normal & 1010 & 98.9 \\
Total & 1021 & 100.0 \\
\hline
\end{tabular}

\begin{tabular}{|lcc|}
\hline \multicolumn{3}{|c|}{ Table 5. Biomicroscopic findings in the lens } \\
Findings & Number of persons & Percentage (\%) \\
Mittendorf point & 5 & 0.5 \\
Iris pigment on the & 6 & 0.6 \\
$\quad$ anterior capsula & & \\
Anterior cortical opacity & 1 & 0.1 \\
Posterior cortical opacity & 3 & 0.3 \\
Posterior capsular opacity & 8 & 0.8 \\
Posterior subcapsular & 1 & 0.1 \\
$\quad$ cataract & & \\
Normal & 996 & 97.6 \\
Total & 1020 & 100.0 \\
\hline
\end{tabular}

Differently from other data, embryonal congenital diseases were more prevalent when compared to the general population, since they are usually diagnosed in school-age individuals ${ }^{(5)}$.

Eyelid examination demonstrated that blepharitis (3.5\%), and meibomitis $(1.1 \%)$ were more prevalent than in other studies, contrary to hordeolum $(0.2 \%)$, whose results were similar ${ }^{(5)}$.

The presence of follicles $(4.2 \%)$ represented the most frequent finding in conjunctival examination, similar to other studies in children ${ }^{(4)}$. However, such studies point to the fact that in this type of population trachoma is classified as a public health problem, which calls for a more detailed investigation to determine its prevalence ${ }^{(6-8)}$.

Pinguecula presented a slightly higher prevalence than in some studies from other countries, a fact explained by the coastal location of Natal, leading to solar elastosis of its inhabitants ${ }^{(9)}$. Pterygium was also slighty less frequent when compared to literature data; this is due to the small number of adults in the study, despite greater exposure to ultraviolet rays in this region ${ }^{(9)}$.

The most common findings by the cornea examination were nubecula, superior pannus and leukoma (possibly cicatricial). However, their prevalences did not attain the levels reported in other studies, which, once again, included a greater number of adults. Due to the small number of adults in our study, no typical findings of senile corneal degeneration were observed ${ }^{(9-10)}$.

The prevalence of iris nevus and corectopia was similar to other data. However, pupillary membrane reliquiae, the most frequent finding, was more prevalent when compared to other studies $^{(5)}$. 
Pupillary membrane reliquiae is an embryonal remnant which may regress over the years becoming less evident in adults, that explains its greater frequency, compared to studies of adult populations ${ }^{(5)}$.

Because the studied population is young, the most frequent lens findings were opacifications related to embryonal reliquiae $^{(3,11)}$. No senile cataracts were detected, contrary to studies of the general population. However, posterior capsular opacity, capsular pigment on the iris and Mittendorf point were the most evident lens changes. The increased prevalence of hyaloid arteria reliquiae in relation to referential studies is thus explained, since this finding represents also an embryonal remnant and is more frequently diagnosed in children ${ }^{(5)}$.

Further studies on the prevalence of biomicroscopic findings in children are necessary in order to obtain a better profile of each population, since children have characteristics which distinguish them from the general population.

\section{CONCLUSION}

The most prevalent findings affected most frequently the external structures of the eye, such as eyelids and conjunctiva in the form of inflammatory diseases of the eyelids (blepharitis) and follicular reaction of the conjunctiva. The most common abnormalities of the cornea, iris, crystalline and anterior vitreous were nubecula, pupillary membrane reliquiae, posterior capsular opacity and hyaloid membrane reliquiae.

\section{RESUMO}

Objetivo: Determinar a prevalência dos achados oculares das estruturas externas e segmento anterior do olho detectados ao exame biomicroscópico em uma população de estudantes de Natal (RN) - Brasil. Métodos: 1024 escolares do ensino fundamental e médio de escolas públicas e privadas da cidade de Natal foram avaliados de março a junho de 2001 após seleção randomizada prévia. Todos foram submetidos a protocolo de pesquisa pré-estabelecido consistindo em identificação, dados demográficos e exame oftalmológico biomicroscópico com lâmpada de fenda, realizados por oftalmologistas do Hospital Universitário Onofre Lopes. Resultados: As alterações da conjuntiva e das pálpebras foram as mais prevalentes, $(10,4 \%$ e $6,2 \%$ respectivamente). Dentre estas, folículos e pa- pilas conjuntivais representaram os achados mais evidenciados ao exame da conjuntiva ( $4,2 \%$ e $3,0 \%$ respectivamente), ao passo que blefarite anterior $(3,5 \%)$ e meibomite $(1,1 \%)$ foram as anormalidades mais encontradas nas pálpebras. Ao exame da córnea, íris, cristalino e vítreo anterior, os achados mais freqüentes foram: nubécula $(0,5 \%)$, restos da membrana pupilar $(0,5 \%)$, opacidade de cápsula posterior $(0,8 \%)$ e resquício da artéria hialóide $(2,0 \%)$. Conclusão: Os achados mais prevalentes acometeram com maior freqüência as estruturas externas do olho (pálpebras e conjuntivas), tendo como seus principais representantes a blefarite anterior e reação folicular da conjuntiva, respectivamente. Já as anormalidades mais evidenciadas na córnea, íris, cristalino e vítreo anterior foram: nubécula, resquício da membrana pupilar, opacidade da cápsula posterior e resquício da artéria hialóide, nesta ordem.

Descritores: Segmento anterior do olho/patologia; Oftalmopatias/epidemiologia; Saúde escolar; Testes visuais; Técnicas de diagnóstico oftalmológico; Estudos transversais

\section{REFERENCES}

1. Rahi JS, Dezateux C. The future of preschool vision screening services in Britain. BMJ. 1997;315(7118):1247-8

2. Wormald R. Screening in ophthalmology. In: Johnson GJ, Minassian DC, Weale R, editors. The epidemiology of eye diseases. London: Chapman and Hall Medical; 1998. p.83-100.

3. Leske MC, Connell AM, Wu SY, Hyman L, Schachat A. Prevalence of lens opacities in the Barbados Eye Study. Arch Ophthalmol. 1997;115(1):105-11.

4. Wedner SH, Ross DA, Balira R, Kaji L, Foster A. Prevalence of eye diseases in primary school children in a rural area of Tanzania. $\mathrm{Br} \mathrm{J}$ Ophthalmol. 2000;84(11):1291-7.

5. Johnson GJ, Green JS, Paterson GD, Perkins ES. Survey of ophthalmic conditions in a Labrador community: II. Ocular disease. Can J Ophthalmol. 1984;19(5):224-33.

6. West SK, Muñoz B, Turner VM, Mmbaga BB, Taylor HR. The epidemiology of trachoma in central Tanzania. Int J Epidemiol. 1991;20(4):1088-92.

7. Tielsch JM, West KP Jr, Katz J, Keyuan-Larijani E, Tizazu T, Schwab L, et al. The epidemiology of trachoma in southern Malawi. Am J Trop Med Hyg. 1988; 38(2):393-9.

8. West S, Muñoz B, Lynch M, Kayongoya A, Chilangwa Z, Mmbaga BB, Taylor HR. Impact of face-washing on trachoma in Kongwa, Tanzania. Lancet. 1995;345(8943):155-8.

9. Norn MS. Prevalence of pinguecula in Greenland and in Copenhagen, and its relation to pterygium and spheroid degeneration. Acta Ophthalmol (Copenh). 1979;57(1):96-105.

10. Johnson GJ. Aetiology of spheroidal degeneration of the cornea in Labrador. Br J Ophthalmol. 1981;65(4):270-83.

11. Leibowitz HM, Kreuger DE, Maunder LR. The Framinghan Eye Study monograph: an ophthalmological Symposium on Circupolar Health. Copenhagen, 1981. Copenhagen: Nordic Council for Arctic Medical Research; 1981. p.352-9.

\section{ABO ELETRÔNICO}

\section{Acesso: http://www.abonet.com.br}

